\title{
NRXN1 Gene Product
}

National Cancer Institute

\section{Source}

National Cancer Institute. NRXN1 Gene Product. NCI Thesaurus. Code C123279.

A protein encoded by the NRXN1 gene. 